\title{
EDEN BOWER - O CARAMANCHÃO DO EDEN
}

\section{Maria Isabel de Andrade} Alonso*
* isabelandrade2004@yahoo.com.br

Formada em letras, licenciatura Português e Italiano, e mestre em Estudos Literários, ambos pela FALE-UFMG
A tradução a seguir é parte constituinte da minha dissertação de mestrado, intitulada Lilith: um monstro feminino em Jorge Luis Borges, Dante Gabriel Rossetti e Primo Levi, defendida na UFMG em Janeiro de 2011.

O poema traduzido, “Eden Bower”, é de autoria de Dante Gabriel Rossetti, 1828-1882, poeta e pintor inglês pré-rafaelita que viveu na Inglaterra durante o período vitoriano. Rossetti tinha enorme interesse pela arte romântica, tendo sido um dos fundadores do pré-rafaelismo, movimento cujos adeptos acreditavam na reação ao academicismo inglês do período, que se baseava na arte clássica do Renascimento na produção artística. Os pré-rafaelitas afirmavam a arte pela arte e desejavam devolver a ela uma beleza poética, algo que existiria além do possível e que eles acreditavam ter sido perdido pelos artistas ingleses de então.

O poema, cujo título faz uma referência ao caramanchão do Éden, hipotetisa a trajetória de Lilith no Paraíso, dando origem a uma narrativa diversa daquela tradicional, segundo a qual Eva teria sido a primeira e única mulher de Adão. Ao contrário, no poema lê-se Lilith e sua vingança, que acaba por gerar desdobramentos e infortúnios não só para Adão e Eva, mas também para a sua prole. 
1. SHEFER, Elaine. "A Rossetti Portrait: Variation on a Theme". Arts in Virginia 27 (1987): 2-15.
Segundo Elaine Shefer, Rossetti era, essencialmente, um pintor de figuras femininas, muitas delas mulheres que faziam parte de sua vida e outras figuras simbólicas, para as quais dedicou inúmeros poemas. ${ }^{1}$ Lilith aparece pelo menos em dois momentos de sua obra: em "Eden Bower", como dito, e em um quadro de nome "Lady Lilith", de 1868, no qual se pode ver figura feminina de longos cabelos ruivos, se penteando em um chambre. A atmosfera é misteriosa, repleta de elementos de sedução, bem como roupas que destoam daquelas adotadas no período vitoriano: ela apresenta cores claras, leves e um grande decote deixando à mostra o colo. Esse quadro apareceria, então, como uma afronta à arte daquele tempo, já que o período vitoriano foi marcado pelo recato das mulheres, que usavam roupas pesadas, duras, que limitavam os movimentos naturais. Nesse sentido, a idealização feminina corrente no período construía mulheres fracas e frágeis, indo de encontro a esse ideal a imagem de Lilith retratada por Rossetti. A figura de Lilith, assim, parece representar, no período vitoriano, a rebeldia aos costumes e aos princípios artísticos vigentes. Também a esse quadro, Rossetti dedicou o poema "Lilith para uma pintura":

Assim, como foi dito, "Eden Bower" é uma narrativa extensa, com 49 estrofes, sobre o mito de Lilith. De forma resumida, pode-se dizer que ela teria convencido a serpente do Éden a emprestar-lhe sua forma para que, uma vez expulsa do Paraíso e proibida de retornar, pudesse entrar sem ser percebida e vingar-se de Adão e Eva. A seguir, o poema e sua tradução. 


\section{EDEN BOWER}

It was Lilith the wife of Adam

(Eden bower's in flower.)

Not a drop of her blood was human,

But she was made like a soft sweet woman.

Lilith stood on the skirts of Eden;

(And O the bower of the hour!)

She was the first that thence was driven;

With her was hell and with Eve was heaven.

In the ear of the Snake said Lilith :-

(Eden bower's in flower.)

'To thee I come when the rest is over;

A snake was I when thou wast my lover.

I was the fairest snake in Eden

(And $\mathrm{O}$ the bower and the hour!)

By the earth's will, new form and feature

Made me a wife for the earth's new creature.

Take me thou as I come from Adam:

(Eden bower's in flower.)

Once again shall my love subdue thee;

The past is past and I am come to thee.

\section{O CARAMANCHÃO DO EDEN}

Era Lilith a mulher de Adão

(os jardins estão floridos.)

Embora nada em seu sangue humano fosse,

Foi feita ela uma mulher suave e doce.

Lilith erguia-se às margens do Éden,

florescia o momento!)

Ela foi a primeira que de lá se leva,

Com ela estava o inferno e o paraíso com Eva.

Ao ouvido da serpente disse Lilith: -

(os jardins estão floridos.)

A ti eu venho quando tudo acabado,

Uma serpente eu era quando tu foste meu amado.

Eu era a mais bela serpente do Éden,

(e o jardim e o momento!)

Pelo desejo da Terra nova forma e mesura

Fez-me uma esposa para a nova criatura.

Toma-me ti quando venho de Adão

(os jardins estão floridos.)

Uma vez mais deve meu amor dominar-te

O passado é passado e vou a ti. 
'O but Adam was thrall to Lilith! And $\mathrm{O}$ the bower and the hour!)

All the threads of my hair are golden,

And there in a net his heart was holden.

'O and Lilith was queen of Adam!

(Eden bower's in flower.)

All the day and the night together

My breath could shake his soul like a feather.

'What great joys had Adam and Lilith!And $\mathrm{O}$ the bower and the hour!)

Sweet close rings of the serpent's twining

As heart in heart lay sighing and pining.

What bright babes had Adam and Lilith!(Eden bower's in flower.)

Shapes that coiled in the woods and waters,

Glittering sons and radiant daughters.

'O thou God, the Lord God of Eden!

(And $\mathrm{O}$ the bower and the hour!)

Say, was this fair body for no man,

That of Adam's flesh thou mak'st him a woman?
O mas Adão era servo de Lilith!

(e o jardim e o momento!)

Cada fio em meu cabelo era dourado,

E nele em uma rede seu coração estava atado.

Ó e Lilith foi a rainha de Adão!

(os jardins estão floridos.)

Inseparáveis noite e dia

Sua alma como uma pena meu fôlego balançaria.

Quanta alegria tiveram Lilith e Adão! -

(e o jardim e o momento!)

anéis sufocantes da serpente girando

corações deitados de saudade suspirando

Bebês magníficos tiveram Lilith e Adão! -

(os jardins estão floridos.)

Nos bosques e rios figuras andantes,

Filhos radiosos e filhas brilhantes.

Ó Deus, o senhor Deus do Éden!

(e o jardim e o momento!)

Diga, criado foste este belo corpo em vão,

Para que outra tirastes da carne de Adão? 
'O thou Snake, the King-snake of Eden! (Eden bower's in flower.)

God's strong will our necks are under,

But thou and I may cleave it in sunder.

'Help, sweet Snake, sweet lover of Lilith! (And $\mathrm{O}$ the bower and the hour!)

And let God learn how I loved and hated Man in the image of God created.

'Help me once against Eve and Adam! (Eden bower's in flower.)

Help me once for this one endeavour

And then my love shall be thine for ever!

'Strong is God, the fell foe of Lilith

(And O the bower and the hour!)

Nought in heaven or earth may affright him;

But join thou with me and we will smite him.

'Strong is God, the great God of Eden:

(Eden bower's in flower.)

Over all he made he hath power;

But lend me thou thy shape for an hour!
Ó tu serpente, a serpente-rei do Éden!

(os jardins estão floridos.)

Rastejantes somos por Deus desejá-lo,

mas podemos nós seu desejo dissipá-lo.

Ajude, doce serpente, amante terno de Lilith!

(e o jardim e o momento!)

E deixe que Deus aprenda como tenho amado e odiado

O homem à imagem de Deus criado.

Ajude-me uma vez contra Eva e Adão!

(os jardins estão floridos.)

Ajude-me uma vez nessa empreitada,

E então para sempre serei tua amada.

Forte é Deus, o cruel inimigo de Lilith:

(e o jardim e o momento!)

Nada no céu ou na terra deve assustá-lo

Mas juntos tu e eu, nós podemos derrotá-lo.

Forte é Deus, o grande Deus do Éden: (os jardins estão floridos.)

Sobre tudo criado por Ele, poder Ele tem;

Mas por uma hora empreste-me tua imagem! 
'Lend thy shape for the love of Lilith!

(And $\mathrm{O}$ the bower and the hour!)

Look, my mouth and cheek are ruddy,

And thou art cold, and fire is my body.

'Lend thy shape for the hate of Adam!

(Eden bower's in flower.)

That he may wail my joy that forsook him,

And curse the day when the bride-sleep took him.

'Lend thy shape for the shame of Eden!

(And O the bower and the hour!)

Is not the foe-God weak as the foeman

When love grows hate in the heart of a woman?

'Would'st thou know the heart's hope of Lilith?

(Eden bower's in flower.)

Then bring thou close thine head till it glisten

Along my breast, and lip me and listen.

'Am I sweet, O sweet Snake of Eden?

(And $\mathrm{O}$ the bower and the hour!)

Then ope thine ear to my warm mouth's cooing

And learn what deed remains for our doing.
Empreste-me tua imagem pelo amor de Lilith!

(e o jardim e o momento!)

Veja, tenho boca e face corada,

e fogo é meu corpo, e tu és gelada.

Empreste-me tua imagem pelo ódio de Adão!

(os jardins estão floridos.)

Que ele lamente minha alegria que o abandonou,

E pragueje o dia que o sono de noiva o embriagou.

Empreste-me tua imagem pela vergonha do Éden! (e o jardim e o momento!)

Não é Deus tão fraco feito homem quando opositor

se no coração de mulher o ódio se torna amor?

Poderias tu conhecer a esperança no coração de Lilith?

(os jardins estão floridos.)

Então traga perto tua cabeça até que ela brilhe,

Beije-me e escute-me, em meu peito se incline.

Sou eu terna, ó doce serpente do Éden?

(e o jardim e o momento!)

Então para o murmúrio de meus lábios quentes incline teu ouvido

E aprenda o que restou a nós ainda não cumprido. 
'Thou didst hear when God said to Adam:-

(Eden bower's in flower.)

"Of all this wealth I have made thee warden;

Thou'rt free to eat of the trees of the garden

"Only of one tree eat not in Eden;

(And $\mathrm{O}$ the bower and the hour!)

All save one I give to thy freewill,-

The Tree of the Knowledge of Good and Evil."

'O my love, come nearer to Lilith!

(Eden bower's in flower.)

In thy sweet folds bind me and bend me,

And let me feel the shape thou shalt lend me!

'In thy shape I'll go back to Eden;

(And O the bower and the hour!)

In these coils that Tree will I grapple,

And stretch this crowned head forth by the apple.

'Lo, Eve bends to the breath of Lilith!

(Eden bower's in flower.)

O how then shall my heart desire

All her blood as food to its fire! "ouviste bem quando Deus disse a Adão: -

(os jardins estão floridos.)

De toda essa riqueza que lhe fiz guardião ser;

Tu és livre para das árvores do jardim comer:

“apenas de uma árvore não coma no Éden”;

(e o jardim e o momento!)

Todas menos uma ao teu livre arbítrio dou meu aval;

A árvore do conhecimento do bem e do mal.

Ó meu amor, venha mais perto de Lilith!

(os jardins estão floridos.)

Em suas curvas enrosque-me e enrole-me,

E me deixe sentir a forma que irá emprestar-me!

Em teu formato voltarei ao Éden;

(e o jardim e o momento!)

Nesses movimentos aquela árvore irei escalar,

E em direção à maçã a cabeça irei guiar.

Veja, Eva inclina-se para o suspiro de Lilith!

(os jardins estão floridos.)

O, como então deve meu coração desejar

Todo seu sangue como alimento queimar! 
'Lo, Eve bends to the words of Lilith!-

(And $\mathrm{O}$ the bower and the hour!)

"Nay, this Tree's fruit,--why should ye hate it,

Or Death be born the day that ye ate it?

"Nay, but on that great day in Eden,

(Eden bower's in flower.)

By the help that in this wise Tree is,

God knows well ye shall be as He is."

'Then Eve shall eat and give unto Adam;

(And O the bower and the hour!)

And then they both shall know they are naked,

And their hearts ache as my heart hath ached.

'Aye, let them hide in the trees of Eden, (Eden bower's in flower.)

As in the cool of the day in the garden

God shall walk without pity or pardon.

'Hear, thou Eve, the man's heart in Adam! (And $\mathrm{O}$ the bower and the hour!)

Of his brave words hark to the bravest:-

"This the woman gave that thou gavest." "veja, Eva inclina-se às palavras de Lilith! -

(e o jardim e o momento!)

Não, esse fruto da árvore - porque odiado seria?

Ou deveria a morte nascer naquele dia?

Não, mas naquele grande dia no Éden,

(os jardins estão floridos.)

Pela ajuda que nessa sábia árvore é,

Deus sabe bem que você deve ser como Ele é.

Então Eva deve comer e dá-la a Adão;

(e o jardim e o momento!)

Então que estão nus ambos devem reconhecer,

E como doeu meu coração, os deles hão de doer.

Sim, deixe-os esconder nas árvores do Éden, (os jardins estão floridos.)

No frio dos dias no jardim então

Deus deve caminhar sem pena ou perdão.

Escute, Eva, o coração de homem de Adão!

(e o jardim e o momento!)

De suas palavras valentes atenha-se nestas que disseste:

"esta mulher me deu o que você me deste." 
'Hear Eve speak, yea, list to her, Lilith!

(Eden bower's in flower.)

Feast thine heart with words that shall sate it-

"This the serpent gave and I ate it."

'O proud Eve, cling close to thine Adam,

(And O the bower and the hour!)

Driven forth as the beasts of his naming

By the sword that for ever is flaming.

'Know, thy path is known unto Lilith!

(Eden bower's in flower.)

While the blithe birds sang at thy wedding,

There her tears grew thorns for thy treading.

'O my love, thou Love-snake of Eden!

(And O the bower and the hour!)

O to-day and the day to come after!

Loose me, love,--give breath to my laughter!

'O bright Snake, the Death-worm of Adam!

(Eden bower's in flower.)

Wreathe thy neck with my hair's bright tether,

And wear my gold and thy gold together!
Escute Eva falar, sim, escute-a, Lilith!

(os jardins estão floridos.)

Deleite teu coração com palavras que podem satisfazer a ti.

"Isso a serpente me deu e eu comi".

Ó Eva orgulhosa, aproxime-se de teu Adão,

(e o jardim e o momento!)

Expulsos como os seres que ele nomeou,

Pela espada que para sempre flamejou.

Sabes, teu caminho é conhecido para Lilith!

(os jardins estão floridos.)

Enquanto alegres pássaros em teu casamento cantaram,

Lá suas lágrimas cresciam pelo que a ela tramaram.

Ó meu amor, serpente do amor do Éden!

(e o jardim e o momento!)

Ó hoje e o dia que está por vir!

Relaxe-me, ame, dê-me fôlego quando eu rir!

Ó serpente brilhante, o verme da morte de Adão! (os jardins estão floridos.)

Com a coleira dos meus cabelos enrosque o pescoço teu,

E vista juntos teu ouro e o ouro meu. 
'On that day on the skirts of Eden,

(And $\mathrm{O}$ the bower and the hour!)

In thy shape shall I glide back to thee,

And in my shape for an instant view thee.

'But when thou'rt thou and Lilith is Lilith,

(Eden bower's in flower.)

In what bliss past hearing or seeing

Shall each one drink of the other's being!

"With cries of "Eve!" and "Eden!" and "Adam!" (And $\mathrm{O}$ the bower and the hour!)

How shall we mingle our love's caresses,

I in thy coils, and thou in my tresses!

'With those names, ye echoes of Eden,

(Eden bower's in flower.)

Fire shall cry from my heart that burneth,-

"Dust he is and to dust returneth!"

'Yet to-day, thou master of Lilith,-

(And O the bower and the hour!)

Wrap me round in the form I'll borrow

And let me tell thee of sweet tomorrow.
Naquele dia nas margens do Éden,

(e o jardim e o momento!)

No teu formato devo eu silenciosamente ir de volta a ti.

$\mathrm{E}$ em minha forma por um instante ver a ti.

Mas quando tu és tu e Lilith é Lilith,

(os jardins estão floridos.)

Em que êxtase depois de ouvir ou ver

Do ser do outro deve cada um beber!

Com lamentos de "Eva! "Éden! e Adão!"

(e o jardim e o momento!)

Como podemos nós trocar de amor nossas deixas,

Eu em tuas voltas, e tu em minhas madeixas.

Com esses nomes, seus ecos do Éden,

(os jardins estão floridos.)

Fogo deve chorar do meu coração que queimarás, -

"do pó vieste e ao pó retornarás!"

Ainda hoje, tu, mestre de Lilith,

(e o jardim e o momento!)

Cubra-me com a forma que tomarei para mim

E deixe-me falar-te do doce amanhã enfim. 
In the planted garden eastward in Eden,

(Eden bower's in flower.)

Where the river goes forth to water the garden,

The springs shall dry and the soil shall harden.

'Yea, where the bride-sleep fell upon Adam,

(And $\mathrm{O}$ the bower and the hour!)

None shall hear when the storm-wind whistles

Through roses choked among thorns and thistles.

'Yea, beside the east-gate of Eden,

(Eden bower's in flower.)

Where God joined them and none might sever,

The sword turns this way and that for ever.

'What of Adam cast out of Eden?

(And O the bower and the hour!)

Lo! with care like a shadow shaken,

He tills the hard earth whence he was taken.

'What of Eve too, cast out of Eden?

(Eden bower's in flower.)

Nay, but she, the bride of God's giving,

Must yet be mother of all men living.
No jardim plantado ao leste do Éden,

(os jardins estão floridos.)

Onde o rio vai o jardim molhar,

O solo deve ser árido e a primavera secar.

Sim, onde o sono de noiva caiu sobre Adão,

(e o jardim e o momento!)

Ninguém deve ouvir o vento da tempestade pelos caminhos

Através de rosas sufocadas, cardos e espinhos

Sim, ao portão leste do Éden,

(os jardins estão floridos.)

Onde Deus uniu-os e ninguém deve torná-los metade

A espada toma esse caminho por toda a eternidade.

E Adão expulso do Éden?

(e o jardim e o momento!)

Veja! Com cuidado como um laivo abalado

Ele cultiva a terra dura de onde foi levado.

E Eva também expulsa do Éden?

(os jardins estão floridos.)

Não, mas dela, a noiva por Deus criada,

Toda a humanidade deve ainda ser gerada. 
'Lo, God's grace, by the grace of Lilith!

(And $\mathrm{O}$ the bower and the hour!)

To Eve's womb, from our sweet to-morrow,

God shall greatly multiply sorrow.

'Fold me fast, O God-snake of Eden!

(Eden bower's in flower.)

What more prize than love to impel thee?

Grip and lip my limbs as I tell thee!

'Lo! two babes for Eve and for Adam

(And $\mathrm{O}$ the bower and the hour!)

Lo! sweet Snake, the travail and treasure,-

Two men-children born for their pleasure!

'The first is Cain and the second Abel:

(Eden bower's in flower.)

The soul of one shall be made thy broth er,

And thy tongue shall lap the blood of the other.'

(And O the bower and the hour!)
Veja, a graça de Deus, pela graça de Lilith!

(e o jardim e o momento!)

Para o útero de Eva, do doce tempo que irá chegar,

Deve Deus grandemente multiplicar o pesar.

Envolva-me rápido, ó serpente deus do Éden!

(os jardins estão floridos.)

Que outro prêmio além do amor devo levar a ti?

Aperte e beije meus membros como eu disse a ti!

Veja! Dois bebês para Eva e Adão!

(e o jardim e o momento!)

Veja! Doce serpente, a dor e o valioso

Dois garotos nascidos para seu gozo!

O primeiro é Caim e o segundo Abel:

(os jardins estão floridos.)

A alma de um irmão deve se tornar,

E tua língua o sangue do outro sugar.

(e o jardim e o momento!) 